УДК $327.8: 327.2$

Семчинський Костянтин Валерійович https://orcid.org/0000-0002-3125-340 кандидат філософських наук, доцент Київський університет культури, Київ, Україна, semchynskyy@gmail.com

\title{
АГРЕСІЯ РОСІЙСЬКОЇ ФЕДЕРАЦІЇ ПРОТИ УКРАЇНИ В КОНТЕКСТІ РОСІЙСЬКОӤ ГЕОСТРАТЕГІЇ НА ПОСТРАДЯНСЬКОМУ ПРОСТОРІ
}

В умовах агресії Російської Федерації проти України особливості російської геостратегії на пострадянському просторі постають актуальним питанням. Метою дослідження $є$ визначити інструменти поширення Росією геополітичного впливу і механізм реалізації нею геостратегічних інтересів на пострадянському просторі та дослідити негативний вплив зовнішньої політики РФ та іiї геостратегії в цілому на архітектуру європейської безпеки та сучасний світовий порядок. Застосувавши системні, аналітичні і компаративні методи, автор робить невтішний висновок про те, що у нинішньому вигляді і 3 нинішнім керівництвом Росія не здатна на конструктивні дії у міжнародному середовищі, а навпаки - дестабілізує сучасну систему міжнародних відносин. В результаті дослідження автор визначає нинішню Росію як загрозу міжнародному миру та безпеці, неоімперіалістичною агресивною силою, державою-терористом, яка планує деструктивну трансформацію сучасної системи міжнародних відносин. У висновках виявлено низку характерних особливостей інспірування Російською Федерацією нині заморожених конфліктів на пострадянському просторі в контексті реалізації нею геостратегічних завдань глобального масштабу. Серед них: підступний, агресивний, рефаншистський характер більшості зовнішньополітичних активностей та дій, недолугі спроби позиціонувати себе одним з «полюсів» пост-біполярного світу, брехлива пропаганда, що покликана маскувати як конкретні агресії, так і загальний напрям геостратегії на ревізію міжнародного порядку, очевидний шантаж та залякування світового співтовариства деструктивністю подальших зовнішньополітичних дій. Водночас, автор доходить висновку про те, що причини агресивної зовнішньої політики РФ у пост-біполярний період закладені у природі путінізму як квінтесенції традиційного російського експансіонізму, імпер-шовінізму та злочинної зневаги до норм міжнародного права. Авторською знахідкою є окреслення нового етапу ескалації гібридної агресії РФ проти України.

Ключові слова: агресія, геостратегія, конфлікт, пострадянський простір, вплив. 
Semchynskyi Kostiantyn, Candidate of Philosophy, Associate Professor, Kyiv University of Culture, Kyiv, Ukraine

The Russian Federation aggression against Ukraine in the context of the Russian geostrategy in the post-Soviet space

In the conditions of the Russian Federation aggression against Ukraine, the peculiarities of Russian geostrategy in the post-Soviet space appear to be a topical issue. The purpose of the study is to determine the geopolitical influence of Russia and its implementation of geo-strategic interests in the post-Soviet space, and to investigate the negative influence of Russian foreign policy and its geostrategy as a whole on the architecture of the European security and the modern world order. Applying systematic, analytical and comparative methods, the author makes a disappointing conclusion that, in its present form and with the current leadership, Russia is not capable of constructive action in the international environment, and on the contrary - destabilizes the modern system of international relations. As a result of the study, the author identifies current Russia as a threat to international peace and security, a neo-imperialist aggressive force, a terrorist state that is planning a destructive transformation of the modern system of international relations. The findings revealed a number of characteristic features of the Russian Federation's recent intersection of frozen conflicts in the post-Soviet space in the context of the implementation of its geostrategic tasks of global scale. Among them: the insidious, aggressive, reflexive nature of most foreign-policy activities and actions, obscene attempts to position itself as one of the "poles" of the post-bipolar world, false propaganda designed to disguise as concrete aggressions, and the general direction of geostrategy on the revision of the international order, is obvious blackmail and intimidation of the world community by the destructiveness of further foreign policy actions. At the same time, the author comes to the conclusion that the causes of the aggressive foreign policy of Russia in the post-bipolar period are laid down in the nature of Putinism as the quintessence of traditional Russian expansionism, imperial chauvinism, and criminal contempt for the norms of international law. The author's discovery is the outline of a new stage in the escalation of the RF hybrid aggression against Ukraine.

Key words: aggression, geostrategy, conflict, post-Soviet space, influence.

Семчинский Константин Валерьевич, кандидат философских наук, доиент, Киевский университет культуры, Киев, Украина

Агрессия Российской Федерации против Украины в контексте российской геостратегии на постсоветском пространстве

В условиях агрессии Российской Федерации против Украины особенности российской геостратегии на постсоветском пространстве возникают актуальным вопросом. Целью исследования является определить инструменты распространения Россией геополитического влияния и механизм реализации ней геостратегических интересов на постсоветском пространстве и исследовать негативное влияние 


\section{АГРЕСІЯ РОСІЙСЬКОЇ ФЕДЕРАЦІЇ ПРОТИ УКРАЇНИ В КОНТЕКСТІ РОСІЙСЬКОӤ ГЕОСТРАТЕГІЇ НА ПОСТРАДЯНСЬКОМУ ПРОСТОРІ}

внешней политики РФ и ее геостратегии в целом на архитектуру европейской безопасности и современный мировой порядок. Применив системные, аналитические и компаративные методы, автор делает неутешительный вывод о том, что в нынешнем виде и с нынешним руководством Россия не способна на конструктивные действия в международной среде, а наоборот - дестабилизирует современную систему международных отношений. В результате исследования автор определяет нынешнюю Россию как угрозу международному миру и безопасности, неоимпериалистические агрессивной силой, государством-террористом, которая планирует деструктивную трансформацию современной системы международных отношений. В выводах выявлен ряд характерных особенностей инспирации Российской Федерацией сейчас замороженных конфликтов на постсоветском пространстве в контексте реализации ею геостратегических задач глобального масштаба. Среди них: коварный, агрессивный, рефаншистський характер большинства внешнеполитических активностей и действий, неуклюжие попытки позиционировать себя одним из «полюсов» пост-биполярного мира, лживая пропаганда, которая призвана маскировать как конкретные агрессии, так и общее направление геостратегии на ревизию международного порядка, очевиден шантаж и запугивание мирового сообщества деструктивностью дальнейших внешнеполитических действий. В то же время, автор приходит к выводу о том, что причины агрессивной внешней политики РФ в пост-биполярный период заложены в природе путинизма как квинтэссенции традиционного русского экспансионизма, импер-шовинизма и преступной пренебрежения к нормам международного права. Авторской находкой является определение нового этапа эскалации гибридной агрессии РФ против Украины.

Ключевые слова: агрессия, геостратегия, конфликт, постсоветское пространство, влияние.

Вступ та постановка проблеми. Сьогодні на пострадянському просторі точиться непримириме протистояння між проектом євразійської імперії та національним демократичним державотворенням. Прагнення розбудувати насправді незалежну та ефективну державу наштовхується на опір Кремля, який планує відтворити СРСР на основі власних геостратегічних інтересів та цивілізаційних дороговказів. Саме на прикладі України путінський режим намагається здійснити примусову і показову реінтеграцію пострадянського простору на засадах імперського авторитаризму. І хоча нинішня РФ за своїми військовостратегічними, соціально-економічними та міжнародно-статусними характеристиками є лише примарною подобою могутнього СРСР, вона спромоглася стати загрозою міжнародній безпеці, піддаючи ревізії основи усталеного світового порядку, загрожуючи ескалацією конфліктів на європейському континенті та руйнуванням європейського співтовариства. Постає актуальним охарактеризувати 
етапи реалізації, засоби та особливості російської геостратегії на пострадянському просторі та визначити роль і місце російської агресії проти України у стратегічному плані поширення Російською Федерацією геополітичного впливу на континентальному та глобальному рівнях шляхом здійснення деструктивної зовнішньої політики.

В останніх дослідженнях і публікаціях започатковано розв'язання цієї проблеми: російська агресія всебічно досліджується із самого іiі початку, грунтовні праці О. Задорожнього (Zadorozhnii,20150, В. Горбуліна (Horbulin , 2017), П. ГайНижника (Hai-Nyzhnyk, 2016) присвячені розкриттю ii міжнародно-правових та військово-стратегічних аспектів, питанням національної та міжнародної безпеки після 2014 p. Чимало праць вітчизняних ізарубіжних авторів присвячено особливостям російської геостратегії у пост-біполярний період (Holtsov, 2014; Danylenko, 2018; Kyrylova, 2017). Так, українські дослідники О. Власюк та C. Кононенко (Vlasiuk, 2017) визначають Російську Федерацію як «чинник регресу, джерело хаосу, провокатор конфліктів, адже підтримати свій великодержавний статус [вона] може лише в такий деструктивний спосіб». Водночас варто дослідити негативний вплив російської агресії та геостратегії РФ в цілому на архітектуру європейської безпеки та сучасний світовий порядок.

Виходячи із викладеного вище, автор ставить перед собою такі завдання:

- окреслити етапи і засоби реалізації Росією геостратегічних інтересів на пострадянському просторі та інструменти поширення геополітичного впливу;

- визначити роль контрольованих Кремлем конфліктів як основних механізмів російської геостратегії на теренах колишнього СРСР в процесі реінтеграції останнього;

- виявити перспективи ревізіоністської геостратегії путінської РФ та похідні від неї загрози регіональній безпеці;

- дослідити вплив російської геостратегії на пострадянському просторі на архітектуру європейської безпеки та сучасний світовий порядок.

Виклад основного матеріалу. Геостратегія визначається як обумовлений геополітичними міркуваннями процес реалізації національно-державних інтересів у міжнародному середовищі. Для Росії на регіональному рівні магістральним національно-державним інтересом впродовж чотирьох сотень років було створення своєрідного поясу безпеки із східноєвропейських державних утворень на своїх західних рубежах. Тому західний вектор експансії Московії, на відміну від східного, був не просто «експансією заради експансії», оскільки мав абсолютно практичний безпековий - вимір. Нелояльність Москві хоча б одного елемента цього «поясу безпеки» ставила під загрозу всю безпекову конструкцію.

За радянської окупації були створені такі російськомовні анклави як Придністров'я в Молдові, Нарва в Естонії, Південний Донбас і Крим у складі України, чисельні російські діаспори в Казахстані, Таджикистані та Білорусі. 


\section{АГРЕСІЯ РОСІЙСЬКОЇ ФЕДЕРАЦІЇ ПРОТИ УКРАЇНИ В КОНТЕКСТІ РОСІЙСЬКОӤ ГЕОСТРАТЕГІЇ НА ПОСТРАДЯНСЬКОМУ ПРОСТОРІ}

Впродовж радянської окупації Литви Москва тричі пропонувала Вільнюсу приєднати російськомовну Калінінградську область, однак влада республіки завжди відмовлялась, справедливо вбачаючи у російському анклаві загрозу безпеці і суверенітету у майбутньому. Цим анклавам відводилася особлива роль у системі державної безпеки СРСР в останні роки його існування. Агонізуюча радянська система, намагаючись мімікрувати у відповідності до нових умов, повинна була мати осередки «на місцях» для регенерації, консолідації і подальшої консервації. Російські анклави підходили для цього найкраще. Тому КДБ СРСР, не спромігшись запобігти невідворотному розпаду СРСР, планував відродити підконтрольну цій всесильній спецслужбі неоімперію, поступово розширюючи межі «руського міра» як від центру, так і від осередків на місцях, - i «до самих до окраїн». Задля цього Кремлем застосовувались такі інструменти поширення геополітичного впливу, як: провокування та ескалація конфліктів на національно-етнічному грунті, встановлення квазі-державних режимів на відчужених територіях суверенних держав - колишніх радянських республік, легітимація їх шляхом визнання в односторонньому порядку і підтримка цих режимів військовою силою, а також відкрита або прихована військова агресія.

Контрольовані Кремлем конфлікти на теренах колишнього СРСР покликані консервувати стан невизначеності і нестабільності з метою збереження російської присутності і поширення геополітичного впливу. Як було вже зауважено раніше, відчуження тієї чи іншої території не є кінцевою метою конфлікту, планованого Росією, оскільки не відповідає стратегічним інтересам Кремля, адже саме неврегульовані конфлікти надають останньому можливість впливати на політику тієї чи іншої пострадянської держави упродовж багатьох років. Виходячи з цього, можна дійти висновку, що війна з Грузією 2008 року завершилася для РФ стратегічною поразкою, оскільки Абхазія і Південна Осетія проголосили незалежність, яку Росія не могла не визнати. Грузія визнала фактичну втрату цих територій, позбавивши таким чином Кремль можливості використовувати тліючий конфлікт у своїх інтересах (Semchynskyi, 2018).

Оскільки основним напрямком російської геостратегії було відновлення імперії у межах впливу колишнього СРСР, Москва продовжувала повзучу експансію на пострадянському просторі, підживлюючи міжнаціональні суперечки і використовуючи російські анклави для дестабілізації незрілих політичних систем у республіках та для консервації неорадянської системи управління i господарювання. Механізм контролю за територією передбачав підтримку Кремлем проросійських сил на місцевих виборах $\mathrm{i}$ авторитарних напівкримінальних політичних режимів, які перемогли на таких виборах, аби на десятиліття утвердити відданість Москві на рівні законів і двосторонніх угод із колишньою метрополією, формування п'ятої колони у суспільстві, яке стало об'єктом агресії, створення маріонеткових урядів на захоплених або спірних територіях, або взагалі 
на територіях суверенних держав, проведення плебісцитів на окупованих територіях 3 метою легітимізувати або їхне приєднання до власного політичного союзу, або ж лояльну до агресора організацію у якості «законної народної влади». У другому випадку може йтися про низку заходів підтримки непопулярного i зазвичай антидемократичного, деспотичного режиму - від визнання на міжнародному рівні і послідовної військової, дипломатичної, економічної підтримки агресором до забезпечення ним притулку квазідиктаторові у разі поразки останнього.

Встановлення та підтримка військовою силою квазі-державних режимів на відчужених територіях суверенних держав - колишніх радянських республік, а також легітимація їх шляхом визнання в односторонньому порядку здійснювалося Росією у відповідності із указом президента Сльцина від 1995 p. про оголошення пострадянського простору «зоною інтересів насамперед Росії». Лукаво підміняючи концепт «російський» концептом «російськомовний» Кремль одночасно формулює зовнішньополітичну домінанту про «захист співвітчизників за кордоном», окреслюючи масштаб свого геополітичного впливу територіями, мешканці яких розуміють російську мову, не будучи при цьому ані етнічно «рускімі», ані політично «росіянами». У новітній редакції Стратегії національної безпеки РФ (пункт 8) йдеться вже про те, що «Росія продемонструвала здатність захисту прав співвітчизників за кордоном» (O Strategii natsional'noi bezopasnosti RF..., 2015), що свідчить про успішну реалізацію цього елементу російської геостратегії і життєздатність цієї домінанти у майбутньому. Що ж до геостратегії - мусимо констатувати, що російське керівництво починаючи з 2000 р. обрало шлях потурання ницим інстинктам натовпу, використовуючи гасла про відновлення величі Росії, «вставання 3 колін», «третій Рим», «руський мір» лише як ширму для агресії, експансії та державного тероризму, водночас наповнюючи змістом власну пристрасть до незаконного збагачення.

Геополітичні зміни першого десятиліття XXI ст. змусили Росію вибудовувати нову модель відносин із країнами СНД. Саме у цей час проявляється різне бачення зовнішнього вектору політичними елітами країн колишнього СРСР: на противагу євразійським прагненням керівництва Росії та ії нових сателітів - Білорусі, Казахстану, Вірменії і Киргизстану, на пострадянському просторі починають превалювати тенденції безальтернативної орієнтації на європейські та євроатлантичні структури та інститути (країни Балтії) та спроби сформувати на противагу Росії інтеграційні проекти на кшталт ГУАМ і визначення західного вектору пріоритетним у Грузії, Україні, Азербайджані та Молдові. Захід активно підтримував ці республіки у реалізації фінансованих ним енергетичних проектів, а відтак був зацікавлений у вирішенні застарілих конфліктів на пострадянському просторі. Однак Росія виявилася не лише нездатною врегулювати інспіровані нею конфлікти, але зробила все можливе, аби заморозити їх у своїх інтересах. Водночас, Москвою почали розроблятися сценарії, за якими мали роздмухуватися нові 


\section{АГРЕСІЯ РОСІЙСЬКОЇ ФЕДЕРАЦІЇ ПРОТИ УКРАЇНИ В КОНТЕКСТІ РОСІЙСЬКОӤ ГЕОСТРАТЕГІЇ НА ПОСТРАДЯНСЬКОМУ ПРОСТОРІ}

конфлікти задля поширення і утвердження імперського впливу на пострадянському просторі як ефективний інтрумент російської геостратегії.

Символічним вододілом, який ознаменував настання нового етапу російської політики щодо країн СНД, стала Помаранчева революція в Україні. Якщо до 2004 р. періодичні торговельні війни залагоджувалися методами безкраваткової дипломатії, то після РФ перейшла до повномасштабної переоцінки ролі економічних зв'язків iз країнами СНД (Sushko, 2006). Відтоді інструментами зовнішньополітичного тиску стають «газові» i «торгові» війни у стосунках із тими пострадянськими республіками, політичні еліти яких дозволяли собі демонструвати окремішність від кремлівсько-евразійського вектору у здійсненні внутрішньої і зовнішньої політик, відмінну від російської точку зору щодо місця цих республік у геополітичній картині пост-біполярного світу і невпинну інтеграцію до європейських та - найболючіше для Москви - євроатлантичних структур. Примара «натівських яструбів» закономірно викликала традиційну антиамериканську істерику і детермінувала імплементацію стратегії «оточеної фортеці» як у зовнішніх зносинах, так і на рівні суспільної свідомості - для виправдання провальних економічно-господарських експериментів і маскування тотальної корупції в системі «вертикалі влади».

Варто зауважити також і про нові форми і способи ведення конфліктів на територіях, які становлять геостратегічний інтерес Росії. Пункт 15 Військової доктрини РФ у редакції 2014 р. передбачає: створення на територіях сторін конфлікту постійної зони військових дій; участь у них нерегулярних збройних формувань і приватних військових компаній; застосування непрямих і асиметричних заходів; використання політичних сил, суспільних рухів, які фінансуються та керовані ззовні (Danylenko, 2018). Водночас, до кінця 2013 р. економічна неспроможність Євразійського економічного союзу як самостійного центру тяжіння, завдяки якому Москва могла б вибудовувати рівноправний діалог з Брюсселем і Пекіном, стала очевидною; тому на тлі знову посталої перед Кремлем проблеми європейської інтеграції України Москва вибрала дестабілізацію цієї держави як єдино доступний їй спосіб запобігання такій загрозі.

В контексті реалізації стратегічного плану Путіна - створення російської неоімперії шляхом військового захоплення територій колишніх радянських республік агресія проти України є першим етапом, від успішності реалізації якого залежить подальше переформатування пострадянського простору силовими методами та формування нових кордонів РФ. Наразі відбувається новий етап ескалації гібридної агресії РФ проти України. Кремль значно посилив свою військову присутність в Азовському морі - у жовтні 2018 р. туди передислоковано до 120-ти військових суден та катерів РФ для того, щоб остаточно заблокувати українські морські порти на Азові - Маріуполь та Бердянськ. Росія штучно чинить перепони для пересування українських суден Керченською протокою, завдаючи серйозної шкоди комерційному судноплавству в Азовському морі. Затримуючи українські судна на декілька діб для 
«перевірок», російські прикордонники переслідують ціль і довести до банкрутства українські порти на Азові, критично зменшивши їх товарообіг, і дискредитувати Україну як надійного торгівльного і транзитного партнера. При цьому країна-агресор керується укладеною між нею та Україною у 2004 р. угодою про спільне використання Азовського моря, яка дозволяє Росії оглядати будь-які судна, які видаються їй підозрілими.

Президент України П. Порошенко нещодавно зазначив: «російська агресія заскочила Захід зненацька. Проігноровані були усі важливі сигнали: і провокацію на Тузлі; і відверто агресивний виступ російського президента на Мюнхенському безпековому форумі 2007 р., де він в принципі всіх про все попереджав: і напад у 2008 Росії на Грузію, і перша реакція на окупацію Криму виявилася напрочуд млявою та беззубою» (Pro vnutrishnie ta zovnishnie stanovyshche Ukrainy v 2018 rotsi, 2018). Власне агресія проти України і провела остаточно межу між «м’якою» та «жорсткою» реакцією світової спільноти на реалізацію Російською Федерацією власного геостратегічного сценарію на пострадянському просторі.

У протистоянні на Азовському морі СС чітко став на бік України, вбачаючи у ньому небезпечний прецедент для архітектури європейської безпеки в цілому і загрозу для колишніх радянських республік і країн Східної Свропи. Захід погрожує новими санкціями, оскільки реалізація ревізіоністської геостратегії путінської РФ на пострадянському просторі загрожує безпеці у глобальному масштабі. Із початком агресії проти України російські стратеги поставили на озброєння т. зв. доктрину деескалуючих ядерних ударів. Смисл цієї доктрини в тому, що «при небажаному розвитку військово-політичної ситуації Росія, завдяки властивій Кремлю рішучості та готовності громадян до самопожертви (як упевнені у Кремлі), може завдати обмеженого ядерного удару невеликої потужності без катастрофічних руйнувань, так, щоби противник був поставлений перед вибором - або прийняти російські умови, або почати з нею ядерну війну на знищення» (Yizhak, 2018). Таким чином, високий ризик застосування зброї масового знищення в контексті загальної гонки озброєнь, очевидний шантаж та залякування світового співтовариства підготовкою до нової світової війни та деструктивні зовнішньополітичні дії підтверджують загальний напрям російської геостратегії на ревізію міжнародного порядку.

В умовах нової холодної війни із США та гонки озброєнь Росії вкрай необхідно створити хоча б видимість військової потуги, яка була б адекватною могутності вірогідного супротивника. Такої військової потуги, якою був СРСР часів «другої холодної війни» початку 1980-х рр.: зловісним, жахливим монолітним монстром, розчепірившим щупальця свого впливу по всій земній кулі, загартованим постійною готовністю до ядерного апокаліпсису і наїжаченим задля нього тисячами смертоносних ракет. Проте, нинішня Росія не може порівнюватися із СРСР ні за військовою могутністю, ані за стратегічним потенціалом, ані за масштабом впливу на глобальний політичний процес. Водночас Москва взяла на озброєння 


\section{АГРЕСІЯ РОСІЙСЬКОЇ ФЕДЕРАЦІЇ ПРОТИ УКРАЇНИ В КОНТЕКСТІ РОСІЙСЬКОӤ ГЕОСТРАТЕГІЇ НА ПОСТРАДЯНСЬКОМУ ПРОСТОРІ}

деструктивну великодержавність Радянського Союзу. Сіючи хаос i безлад, провокуючи конфлікти й кризи, здійснюючи підривну діяльність, Росія намагається пересварити між собою і ослабити своїх опонентів аби безумовно домінувати у світовій політиці і нав'язувати свою волю іншим учасникам міжнародних відносин. «Спровокувати конфлікт та створити проблему, а потім нав’язати свої послуги в їх вирішенні - один із зовнішньополітичних методів деструктивної великодержавності» - підкреслюють 3 цього приводу українські дослідники О. Власюк і С. Кононенко (Vlasiuk, 2017, p. 206).

Будучи регіональною азійською сировинно-видобувною країною, федерація прагне посісти вище місце у світовій ієрархії, не маючи жодних потенцій на втілення цих мрій у реальність. Як наслідок - традиційна російська ображеність на міжнародне середовище і прагнення знищити світ, у якому кремлівській імперії немає місця, поєднується з тим, аби панувавати у новому світі із Росією в центрі.

В контексті викладеного вище, деякі автори пропонують Україні «виступити 3 ініціативою розміщення систем ПРО на своїй території (Krapyvenko, 2018). Вважаємо, таке рішення мусить бути підготовлене компетентними органами нашої держави з урахуванням співвідношення потенційних вигід від нього і загроз безпеці, які можуть виникнути внаслідок такого рішення.

Висновки і пропозиції. Окреслення політико-ідеологічних засад нинішньої російської неоімперії дозволило визначити основні напрямки російської геостратегії, механізми реалізації геополітичних інтересів та інструменти поширення геополітичного впливу на пострадянському просторі.

Дослідження сценаріїв відновлення могутності на міжнародній арені, які РФ реалізовуватиме у майбутньому, дозволило зробити невтішний висновок про те, що у нинішньому вигляді і 3 нинішнім керівництвом Росія не здатна на конструктивні дії у міжнародному середовищі, а навпаки - дестабілізує сучасну систему міжнародних відносин. Пропозиції автора 3 цього питання можуть допомогти у подальших дослідженнях російської геостратегії.

Виявлено, що причини агресивної зовнішньої політики РФ у постбіполярний період закладені у природі путінізму як квінтесенції традиційного російського експансіонізму, імпер-шовінізму та злочинної зневаги до норм міжнародного права. Замість того, аби ставати сильнішою, Росія прагне зробити слабшими інших, традиційно ховаючись за спинами мирного населення і біженців, діючи руками заколотників та терористів. У підсумку автором було визначено низку характерних особливостей реалізації Російською Федерацією геостратегії на пострадянському просторі. Серед них: підступний, агресивний, рефаншистський характер більшості зовнішньополітичних активностей та дій, недолугі спроби позиціонувати себе одним з «полюсів» пост-біполярного світу, брехлива пропаганда, що покликана маскувати як конкретні агресії, так і загальний напрям геостратегії на ревізію міжнародного порядку, очевидний шантаж та залякування світового 
співтовариства деструктивністю подальших зовнішньополітичних дій. Автор продемонстрував пряму залежність між російською агресією проти України і кризою сучасної системи міжнародних відносин та системи міжнародного права, фактично інспірованою Росією.

Враховуючи викладене вище, підсумуємо: беручи до уваги статус ядерної держави, економічну неспроможніть, що доповнюється безпідставним прагненням володарювати, та авторитарне управління, можемо стверджувати, нинішня Росія $\epsilon$ загрозою міжнародному миру та безпеці, неоімперіалістичною агресивною силою, державою-терористом, яка планує деструктивну трансформацію сучасної системи міжнародних відносин. Україна має якомога чіткіше дистанціюватися від РФ у здійсненні власної зовнішньої політики, орієнтуючись натомість на Північноатлантичний альянс та Євросоюз задля формування спільної політики протистояння російській експансії, зміцнювати армію та підтримувати боєздатність для відсічі російської агресії у майбутньому, виявляти й попереджати російські загрози українській національній безпеці.

\section{References:}

1. Danylenko, S. (2018). 'Vsiudysushchi spetssluzhby ta nepravdyvi media: typovo radianska dyplomatiia u vykonanni suchasnoi Rosii' [All-round secret services and false media: typically Soviet diplomacy in the performance of modern Russia]. Geostrategy. Global Intelligence Group, [online] Available at: <http://geostrategy.ua/news/vsudisusispecsluzbi-ta-nepravdivi-media-tipovo-radanska-diplomatia-u-vikonanni-sucasnoi-rosii> [Accessed 01.11.2018].

2. Hai-Nyzhnyk, P. P. ed. (2016) Ahresiia Rosii proty Ukrainy: istorychni peredumovy ta suchasni vyklyky [Russia's Aggression Against Ukraine: Historical Backgrounds and Contemporary Challenges]. Kyiv: MP Lesya.

3. Holtsov, A. (2014). 'Imperska heostratehiia Rosiiskoi Federatsii u sviti: osnovni napriamy ta zasoby realizatsii' [Imperial geostrategy of Russian Federation in the world: main directions and realization tools]. Naukovi pratsi Mizhrehionalnoi Akademii Upravlinnia Personalom [Scientific works of Interregional Academy of Personnel Management], no. 42(3), pp. 13-20.

4. Horbulin, V. P. ed. (2017) Svitova hibrydna viina: ukrainskyi front [The world hybryd war: Ukrainian front]. Kyiv: National Institute for Strategic Studies.

5. Krapyvenko, D. (2018). 'Realizuvaty momenty v hibrydnii viini' [To realize the moments in a hybryd war]. Ukrainskyi tyzhden [Ukrainian Week], [online] Available at: <http://tyzhden.ua/Politics/221714> [Accessed 01.11.2018].

6. Kyrylova, K. (2017). 'Nova heostratehiia Rosii: destabilizuvaty Ukrainu i posvaryty YeS iz NATO' [Russia's new geostrategy: destabilizing Ukraine and quarreling the EU with NATO]. Krym. Realii [Crimea. Realities], [online] Available at: < https://ua.krymr.com/a/27248099.html > [Accessed 01.11.2018]. 


\section{АГРЕСІЯ РОСІЙСЬКОЇ ФЕДЕРАЦІЇ ПРОТИ УКРАЇНИ В КОНТЕКСТІ РОСІЙСЬКОЇ ГЕОСТРАТЕГІЇ НА ПОСТРАДЯНСЬКОМУ ПРОСТОРІ}

7. O strategii natsional'noi bezopasnosti RF 31 dekabrya 2015 goda № 683[On the Strategy of the National Security of the Russian Federation on December 31, 2015 No. 683]. Rossijskaja gazeta [Russian newspaper], [online] Available at: <http://rg.ru/2015/12/31/nac-bezopasnost-site-dok.html> [Accessed 01.11.2018].

8. Pro vnutrishnie ta zovnishnie stanovyshche Ukrainy v 2018 rotsi [On the internal and external situation of Ukraine in 2018]. (2018). National Institute for Strategic Studies, [online] Available at: < http://www.niss.gov.ua/articles/3133/> [Accessed 01.11.2018].

9. Semchynskyi, K. (2018). 'Osoblyvosti prymyrennia i myrobudivnytstva v umovakh zamorozhenykh konfliktiv na postradianskomu prostori' [The features of reconciliation and peace building in conditions of frozen conflicts on the post-Soviet space]. Mizhnarodni vidnosyny: teoretyko-praktychni aspekty [International Relations: Theory and Practical Aspects], Vol. 1, pp. 74-84. DOI: https://doi.org/10.31866/2616745x.1.2018.133416.

10. Sushko, O. (2006). 'Rosiia-SND: proshchannia z rehionalnym liderstvom' [Russia-CIS: farewell to regional leadership]. Dzerkalo tyzhnia [Mirror of the week], [online] Available at: <https://dt.ua/POLITICS/rosiyasnd_proschannya_z_regionalnim_liderstvom.html> [Accessed 01.11.2018].

11. Vlasiuk, O. S. (2017). Kremlivska ahresiia proty Ukrainy: rozdumy v konteksti viiny [Kremlin's agression against Ukraine: thoughts in the context of war]. Kyiv: National Institute for Strategic Studies.

12. Yizhak, O. (2018). 'Dedali blyzhche do yadernoho raiu' [Closer to the nuclear paradise]. Dzerkalo tyzhnia [Mirror of the week], [online] Available at: <https://dt.ua/international/dedali-blizhche-do-yadernogo-rayu-292200_.html> [Accessed 01.11.2018].

13. Zadorozhnii, O. (2015). Porushennia ahresyvnoiu viinoiu Rosiiskoi Federatsii proty Ukrainy osnovnykh pryntsypiv mizhnarodnoho prava [Violation of the aggressive war of the Russian Federation against Ukraine basic principles of international law]. Kyiv: K.I.S.

(C) Семчинський К. В., 2019 